\title{
Analisis Kesesuaian Indikator terhadap Kompetensi Dasar pada Pelajaran Matematika oleh Guru Sekolah Menengah Palembang
}

\author{
Indaryanti $^{1}$, Ely Susanti ${ }^{2}$, Nyimas Aisyah ${ }^{3}$, Scristia $^{4 *}$ \\ ${ }^{1234}$ Universitas Sriwijaya, Palembang, Sumatera Selatan 30139, Indonesia
}

Pengiriman: 19 Agustus 2019; Diterima: 23 Oktober 2019; Publikasi: 30 Oktober 2019

DOI: https://doi.org/10.31629/jg.v4i2.1429

\begin{abstract}
Abstrak
Penelitian ini bertujuan untuk mendeskripsikan tingkatan kompetensi serta hierarki kompetensi pada indikator yang dikembangkan oleh 23 guru di Sekolah Menengah yang tersebar di Provinsi Sumatera Selatan, dengan menggunakan acuan penentuan indikator dan tujuan pembelajaran taksonomi Bloom revisi dan Standar Nasional Pendidikan. Hasil analisis menunjukkan adanya ketidaksesuaian tingkat kompetensi pada indikator, dan indikator yang dikembangkan hanya terbatas pada kompetensi minimal pada Kompetensi Dasar.
\end{abstract}

Kata kunci: kompetensi dasar; indikator pembelajaran

\begin{abstract}
This research aims to describe the competence level and competence hierarchy on indicators developed by 23 middle school teachers from South Sumatera Province, using indicator and objectives references to Revised Bloom's Taxonomy and National Standard of Education. The result suggests that the competence levels are overlapping at the indicators and the developed indicators are limited to minimal competence of learning standards.
\end{abstract}

Keywords: learning standard; objectives

\section{Pendahuluan}

Standar Nasional Pendidikan pada Permen No 22 Tahun 2016 tentang Standar Proses dalam lampirannya menjelaskan tentang tugas wajibnya pendidik adalah mempersiapkan perencanaan pembelajaran yang dirancang dalam bentuk Silabus dan Rencana Pelaksanaan Pembelajaran (RPP) yang mengacu pada Standar Isi. Dalam tugas tersebut pendidik diminta untuk mengembangkan Indikator Pencapaian Kompetensi (IPK) pada saat menyusun silabus mata pelajaran, yang telah diuraikan pada Permendiknas Nomor 16 Tahun 2007 tentang Standar Kualifikasi Akademik dan Kompetensi

*Penulis Korespondensi

Email Address: bae_tia@yahoo.com

Handphone : + +6285267488081
Guru. Menurut Nuraeni (2019) dalam pendidikan, tiga hal yang harus dikuasai oleh seorang guru, yaitu kurikulum, proses pembelajaran, dan sistem penilaiannya. Sedangkan pembekalan mengenai aspek perencaanaan dan pelaksanaan pembelajaran diikuti peninjauan mengenai kualitasnya perlu dilaksanakan (Febrian \& Fera, 2019). Sehingga pembekalan terhadap kemampuan guru dalam menganalisa suatu Kompetensi Dasar (KD) juga perlu dilakukan.

Dalam mengembangkan indikator, indikator harus mencapai tingkat kompetensi minimal KD dan pendidik dapat mengembangkan 


\section{JURNAL GANTANG. Oktober 2019; IV(2): 103 - 109 \\ p-ISSN. 2503-0671 \\ e-ISSN. 2548-5547}

melebihi kompetensi minimal tersebut, hal ini dimaksud untuk menyesuaikan dengan kebutuhan peserta didik pada saat penilaian di akhir satuan pendidikan, yaitu Ujian Nasional. Berdasarkan Laporan Hasil Ujian Nasional tahun pelajaran 2017/2018 dari Pusat Penilaian Pendidikan Kementrian Pendidikan dan Kebudayaan diperoleh bahwa rerata nilai mata ujian Matematika untuk SMP tingkat nasional adalah 43,34, sedangkan tingkat Provinsi Sumatera Selatan 38,62 dan Kota Palembang 38,16. Selain itu penelitian yang dilakukan oleh (S, 2017) menunjukkan bahwa guru belum menguasai KD dan Kompetensi Inti (KI). Beberapa pertanyaan terkait hasil tersebut, apakah dari pihak Pemerintah atau dari Pendidik yang keliru menterjemahkan standar proses yang diatur oleh Pemerintah.

Dalam menyampaikan materi secara tuntas guru harus berhasil dalam menterjemahkan KD yang ada dalam kurikulum ke dalam IPK dan tujuan pembelajaran. Sebenarnya pemerintah telah mengeluarkan buku pelajaran Matematika yang dapat digunakan guru serta siswa dalam belajar, dan telah memberikan kemudahan kepada guru dalam menterjemahkan KD. Penulis buku sudah mencantumkan terjemahan KD dalam bentuk pengalaman belajar sehingga guru tinggal mengajarkan materi sesuai KD dan materi pada buku pegangan siswa sudah cukup sesuai dengan KI dan KD (Handayani, 2015). Pengalaman belajar ini bahasa lain untuk menggambarkan tujuan pembelajaran dan IPK. Bila penterjemahan IPK dan tujuan pembelajaran sesuai dengan KD maka diharapkan guru dapat memberikan materi sesuai dengan $\mathrm{KD}$, namun bila sebaliknya maka kemungkinan materi yang disampaikan sesuai atau juga tidak sesuai dengan KD.

Langkah awal yang harus dilakukan pendidik dalam pengembangan indikator adalah menganalisis tingkat kompetensi yang ada pada Kompetensi Inti (KI) dan KD, yang dapat dilihat dari kata kerja operasionalnya. Perlu dipahami pendidik bahwa dalam tingkat kompetensi yang ada pada KD akan terdapat tiga tingkatan yaitu pengetauan, tingkat proses dan tingkat penerapan.
Selain itu, kata kerja yang ada pada KD juga menunjukkan aspek sikap, pengetahuan dan keterampilan. Maka pendidik perlu mengakomodasi kompetensi yang sesuai dengan SK/KI dan KD ketika hendak mengembangkan indikator. Sebagai contoh, jika pada KD aspek keterampilan lebih menonjol maka indikator yang dikembangkan harus mencapai keterampilan minimal yang ada pada $\mathrm{KD}$, dan diingatkan kembali bawa kompetensi pada KD hanya standar minimal, jadi boleh dikembangkan kekompetensi yang lebih tinggi, dan tetap menggambarkan hirarki kompetensi. Aspek penggetahuan, aspek sikap dan aspek keterampilan memiliki klasifikasi kata kerja operasionalnya berdasarkan tingkat kognitif masing-masing yang terukur dan teramati (Anderson et al., 2001).

Dalam kaitannya dengan kompetensi minimal yang ada pada KD, Wardhani (2010) menyebutnya sebagai Indikator Kunci, sehingga guru dalam perencanaannya harus menyatakan secara tertulis di RPP dengan jelas, dan harus terlaksana dalam proses pembelajarannya. Untuk memahami IK, guru harus mengetahui juga indikator yang menjadi prasyarat tercapainya kompetensi yang ada pada IK. Wardhani (2010) menyebutnya sebagai Indikator Pendukung. Namun, dikarenakan pada KD itu hanyalah kompetensi minimal, maka guru perlu mengembangkan indikator yang melebihi dari tuntutan kompetensi minimal $\mathrm{KD}$, dalam hal ini disebut Indikator Kompleks. Selain itu juga, dalam mengembangkan indikator, guru juga harus memikirkan aktivitas pembelajaran yang akan dilakukan dikelas, sehingga apa yang harus siswa pelajari dan apa yang akan guru ajarkan akan jelas tujuannya. Anderson et al (2001) mengkategorikan dimensi pengetahuan tersebut menjadi empat jenis yaitu pengetahuan faktual, pengetahuan konseptual, pengetahuan prosedural, dan pengetahuan metakognitif.

Mengingat tuntutan abad 21 kepada peserta didik nantinya akan semakin saling berkompetensi dan dituntut manusia yang memiliki jiwa problem solver dan pemikir kritis, maka matematika perlu menjadi sarana untuk 
membentuk pola pikir peserta didik yang berpikir secara kritis dalam menyelesaikan permasalahan. Sehingga Higher Order Thinking Skill (HOTS) yang diharapkan pemerintah dapat terwujud.

Penelitian tentang KD yang disusun oleh guru pernah dilakukan oleh Ferozina (2013) dengan menganalisis kesesuaian materi instrumen dengan tuntutan KD. Dalam penelitian Safita secara langsung melihat kesesuaiannya pada materi intrumen bukan melihat pada indikator yang menjadi dasar dari instrumen soal yang di susun. Selanjutnya Hidayah, et al. (2016) yang meneliti kesonsistenan $\mathrm{KI}, \mathrm{KD}$, dan Indikator, hasilnya adalah guru belum konsisten dalam penyusunannya terhadap soal.

Sedangkan pada artikel ini akan mengkaji bagaimana kesesuaian KD dengan indikator yang dikembangkan oleh pendidik apakah hanya mengembangkan indikator sampai batas minimal yang ada pada $\mathrm{KD}$, jika iya, maka kuat dugaan mengapa Ujian Nasional yang soalnya telah menguji ketingkat Higher tidak tercapai, dan tuntutan keterampilan siswa di abad 21 akan sulit untuk terwujud yaitu salah satunya kemampuan berpikir kritis dan pemecahan masalah (Wagner, 2014). Artikel ini juga akan menunjukkan hasil pengembangan indikator oleh pendidik apakah terjadi tumpang tindih indikator atau telah sesuai dengan hierarki kompetensi.

\section{Metode Penelitian}

Penelitian ini merupakan penilitian deskriptif. Subyek penelitian adalah guru Sekolah Menengah di Sumatera Selatan yang tergabung pada Program Pendidikan Profesi Guru (PPG) dalam jabatan di Fakultas Keguruan dan Ilmu Pendidikan (FKIP) Universitas Sriwijaya. Sementara itu yang menjadi objek dalam penelitian ini adalah KD dan Indikator yang dikembangkan oleh guru. Metode yang digunakan metode dokumentasi, denggan cara menganalisis RPP yang disusun oleh Guru. Penelitian ini menganalisis dokumen Pengembanggan Indikator yang telah dikembangkan oleh Guru. Dalam melakukan analisis Peneliti menggunakan pedoman pengembangan Indikator dan Tujuan pembelajaran yang telah didesain oleh Krathwohl versi revisi dari Bloom. Berikut pedoman yang digunakan untuk menganalisis data:

1. KD dikembangkan menjadi beberapa Indikator

2. Indikator menggunakan Kata Kerja Operasional (KKO) yang dapat diukur dan/atau di observasi

3. Indikator dikembangkan dengan prinsip Urgensi, Kontinuitas, Relevansi, dan Konstekstual (UKRK).

4. Tingkat KKO dalam indikator minimal setara dengan kata kerja pada KD

5. KKO indikator harus berorientasi pada materi pokok, bukan berorientasi terhadap tingkatan berpikir yang ada pada kata kerja dalam KD.

\section{Hasil dan Pembahasan}

Berdasarkan hasil analisis tingkat kompetensi yang terdapat pada $\mathrm{KD}$, yaitu dengan menganalisis KKO, tampak pada tabel 1 tersebut indikator pencapaian kompetensi hanya terbatas pada kompetensi minimal pada KD. Dalam hal ini, tuntutan minimal dari kompetensi telah sesuai untuk mencapai standar nasional. Namun hierarki kompetensi yang diharapkan oleh pemerintah dalam Panduan Pengembangan Indikator (Depdiknas, 2010) belum sesuai ketentuan, dengan terlihatnya tumpang tindih tingkat kompetensi. Ada beberapa indikator yang tingkat kompetensinya sudah mencapai level berpikir C3 namun pada indikator berikutnya kembali lagi ke tingkat kompetensi yang lebih rendah yaitu $\mathrm{C} 1$.

Tabel 1 dibawah ini merupakan hasil analisis tingkatan UKRK kompetensi yang telah dilakukan oleh beberapa guru matematika terkait IPK yang telah dikembangkan. Kompetensi yang ada pada indikator kunci telah menunjukkan kompetensi minimal yang ada pada KD. Maksudnya adalah, indikator kunci digunakan untuk mengukur ketercapaian kompetensi KD yang merupakan kompetensi minimal. Misalkan pada KD 3.1 kelas IX, "melakukan operasi bilangan berpangkat bilangan rasional dan bentuk akar, serta sifat-sifatnya". Kompetensi 


\section{JURNAL GANTANG. Oktober 2019; IV(2): 103 - 109 \\ p-ISSN. 2503-0671 \\ e-ISSN. 2548-5547}

minimalnya adalah aplikasi, yaitu kemampuan siswa menggunakan apa yang telah diperolehnya (abstraksi, aturan, dalil, prosedur, metode) dalam situasi khusus baru. Dalam hal ini, "mengaplikasikan" melibatkan pengetahuan konseptual (yakni, pengetahuan tentang jenis atau kategori masalahnya) dan pengetahuan prosedural (yakni, pengetahuan tentang langkah-langkah yang harus dilakukan untuk menyelesaikan masalah). Aktivitas-aktivitas pembelajarannya dapat membantu siswa dalam menguasai kedua pengetahuan tersebut. (Aktivitas tergambar pada tabel 2).

Ketika siswa mengaplikasikan ataupun mengimplementasikan dalam proses pembelajaran sebaiknya guru melakukan aktivitas yang melibatkan pengetahuan metakognitif dengan cara mengajarkan strategi-strategi untuk memonitor jenis masalah yang ada masuk dalam jenis apa. Kemudian jika sudah tahu jenisnya apa, guru juga harus mengingatkan kembali strategistrategi tersebut, kemudian mengajarkan "implementasi" strategi-strategi tersebut, hal inilah yang dimaksud dengan Pengetahuan Metakognitif. Mengapa pengetahuan metakognitif harus ditekankan dalam mencapai pengetahuan konseptual dan prosedural hal ini dikarenakan akan ada kemungkinan kesalahan oleh siswa ketika mereka akan mengaplikasi atau mengimplementasi. Sehingga kompetensi minimal KD 3.1 yaitu "menentukan hasil operasi" tercapai, perhatikan tabel 1 .

Tabel 1

Tingkat kompetensi dan jenis indikator hasil pengembangan guru

\begin{tabular}{|c|c|c|c|}
\hline $\begin{array}{l}\text { Kompetensi Dasar / } \\
\text { Tingkat Kompetensi }\end{array}$ & Indikator Pencapaian Kompetensi yang dikembangkan Guru & $\begin{array}{l}\text { Tingkat } \\
\text { Komp. }\end{array}$ & $\begin{array}{l}\text { Jenis } \\
\text { Indikator }\end{array}$ \\
\hline \multirow{7}{*}{$\begin{array}{lr}3.6 \quad \text { Menjelaskan } \\
\text { Persamaan } & \text { dan } \\
\text { Pertidaksamaan } & \text { Linear } \\
\text { satu variabel } & \text { dan } \\
\text { penyelesaiannya } & \end{array}$} & Menjelaskan nilai kebenaran dari suatu pernyataan & $\mathrm{C} 2$ & Pendukung \\
\hline & Membedakan kalimat eterbuka dan kalimat tertutup & $\mathrm{C} 4$ & Pendukung \\
\hline & Menuliskan ersamaan dan pertidaksamaan linear satu variabel & $\mathrm{C} 1$ & Pendukung \\
\hline & Mengidentifikasi persamaan dan pertidaksamaan linear satu vaiabel & $\mathrm{C} 1$ & Kunci \\
\hline & Menentukan nilai variabel dalam persamaan linear datu varibel & C3 & Kunci \\
\hline & Menentukan nilai variabel dalam pertidaksamaan linear datu varibel & $\mathrm{C} 3$ & Kunci \\
\hline & $\begin{array}{l}\text { Merancang model penyelesaian persamaan linear dan pertidaksamaan linear } \\
\text { satu varibel berkaitan dengan masalah sehari-hari }\end{array}$ & $\mathrm{C} 2$ & Kompleks \\
\hline \multirow{6}{*}{$\begin{array}{l}3.9 \text { Mengenal dan } \\
\text { menganalisis berbagai } \\
\text { situasi terkait artitmatika } \\
\text { social }\end{array}$} & Menentukan nilai keseluruhan nilai unit sebagian, harga jual, dan harga beli & C3 & Pendukung \\
\hline & $\begin{array}{l}\text { Mengidentifikasi hubungna nilai keseluaruhan, nilai unit, harga jual, dan harga } \\
\text { beli }\end{array}$ & $\mathrm{C} 1$ & Kunci \\
\hline & $\begin{array}{l}\text { Memecahkan masalah yang berkaitan dengan untung, rugi, persentase untung, } \\
\text { persentase rugi }\end{array}$ & $\mathrm{C} 5$ & Kunci \\
\hline & Mengidentifikasi hubungan untung ruggi, persentase untung dan rugi & $\mathrm{C} 1$ & Kunci \\
\hline & $\begin{array}{l}\text { Menemukan hubungan diskon, bruto, neto, dan tara persamaan linear datu } \\
\text { varibel }\end{array}$ & C6 & Kunci \\
\hline & Memecahkan masalah tentang bunga tunggal dan pajak & $\mathrm{C} 4$ & Kompleks \\
\hline \multirow{5}{*}{$\begin{array}{l}\text { Menganalisis bangun } \\
\text { datar segiempat dan } \\
\text { segitiga berdasarkan sisi, } \\
\text { sudut, dan hubungan antar } \\
\text { sisi dan antar sudut }\end{array}$} & Mengenal dan memahami bagun datar segiempat dan segitiga & $\mathrm{C} 1$ & Pendukung \\
\hline & $\begin{array}{l}\text { Memahami jenis dan sifat persegi, persegi panjang, tapesium, jajargenjang, } \\
\text { belahketupat, dan layang-layang menurut sifatnya }\end{array}$ & $\mathrm{C} 2$ & Pendukung \\
\hline & $\begin{array}{l}\text { Mengidentifkasi sifat-sifat persegi, persegi panjang, tapesium, jajargenjang, } \\
\text { belahketupat, dan layang-layang yang ditinjau dari sisi, sudut, dan diagonalnya }\end{array}$ & $\mathrm{C} 1$ & Pendukung \\
\hline & Mengklasifikasikan jenis-jenis segitigia berdasarkan sisi dan sudutnya & $\mathrm{C} 2$ & Pendukung \\
\hline & Menemukan jenis segitiga berdasarkan sifat-sifatnya & $\mathrm{C} 4$ & Kunci \\
\hline \multirow{4}{*}{$\begin{array}{l}\text { 3.5 Menjelaskan SPLDV } \\
\text { dan penyelesaiannya yang } \\
\text { dihubungkan dengan } \\
\text { masalah kontekstual }\end{array}$} & Membedakan persamaan linear dua varibel & $\mathrm{C} 2$ & Pendukung \\
\hline & $\begin{array}{l}\text { Menentukan sistem persamaan linear dua variabel yang berhubungan dengan } \\
\text { maslaah konstekstual }\end{array}$ & C3 & Kunci \\
\hline & $\begin{array}{l}\text { Menentukan sistem persamaan linear dua variabel menggunakan metode } \\
\text { grafik, subtitusi, dan eliminasi }\end{array}$ & C3 & Kunci \\
\hline & $\begin{array}{l}\text { Menerapkan metode penyelesaian } \text { SPLDV dalam penyelesaian system } \\
\text { persamaan non linear dua variabel }\end{array}$ & $\mathrm{C} 3$ & Kompleks \\
\hline \multirow{3}{*}{$\begin{array}{l}\text { 3.9 Membedakan dan } \\
\text { menentukan luas } \\
\text { permukaan dan volume } \\
\text { bangun ruang sisi datar }\end{array}$} & Mengambarkan berbagai jenis bangun ruang & $\mathrm{C} 1$ & Kunci \\
\hline & Membedakan bangun ruang dari bidang datar yang membentuknya & $\mathrm{C} 2$ & Kunci \\
\hline & $\begin{array}{l}\begin{array}{l}\text { Menentukan luas permukaan bagun ruang dari bangun datar dan } \\
\text { membentuknya }\end{array} \\
\end{array}$ & C3 & Kunci \\
\hline
\end{tabular}


Indaryanti, Susanti, Aisyah, Scristia: Analisis Indikator...(12)

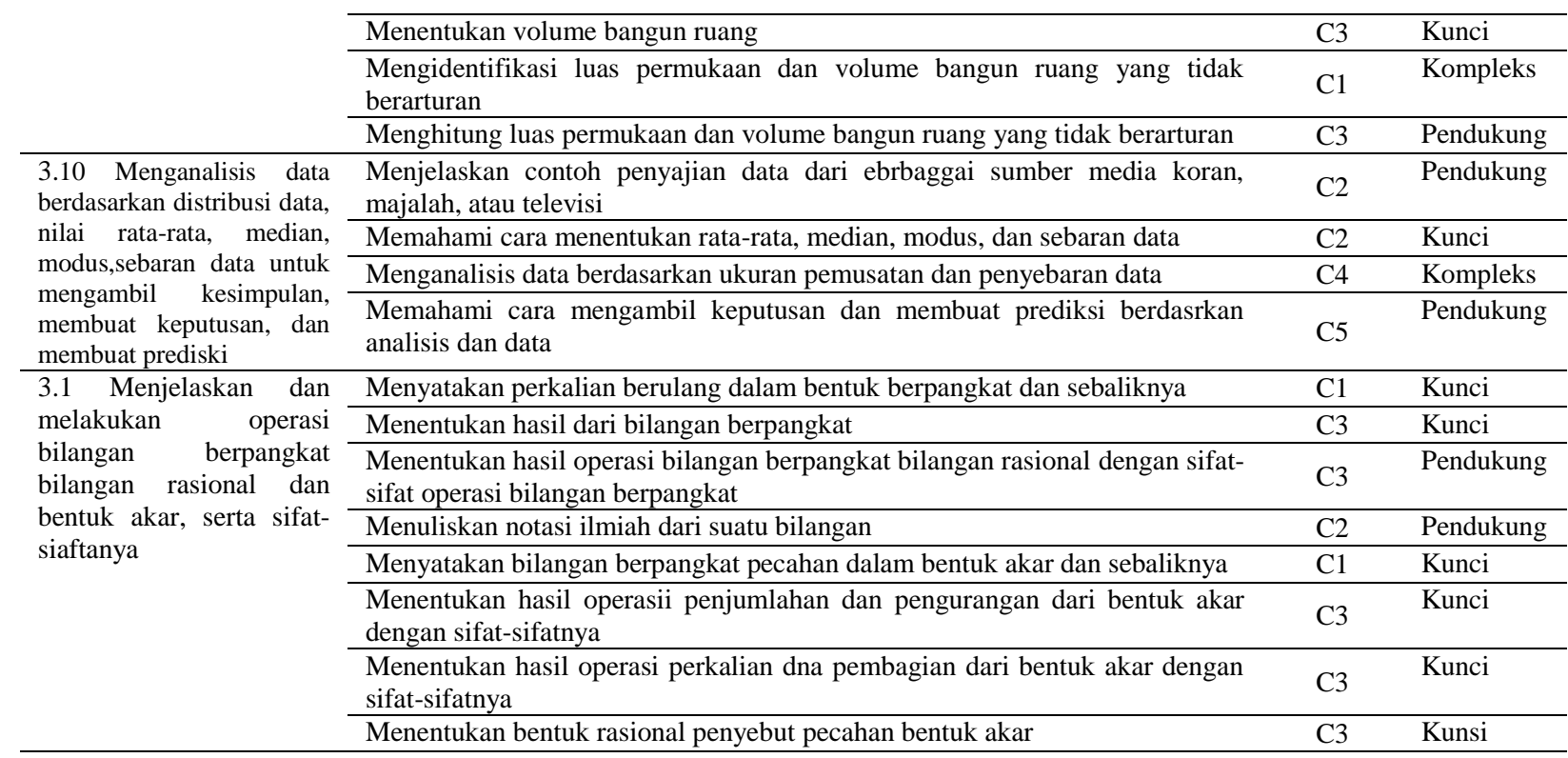

Dalam merancang aktivitas pembelajaran, guru juga harus memahami dimensi dari pengetahuan itu sendiri yang dapat membantu guru dalam memutuskan apa yang perlu diajarkan kepada siswa, dan memandu guru untuk menetapkan apa yang harus dipelajari oleh siswa itu sebabnya ada pengaruh kemampuan guru dalam mengembangkan IPK terhadap kesiapan guru dalam mengajar (Delafani, Holilulloh, \& Nurmalisa, 2014). Pengetahuan konseptual harus diajarkan oleh guru secara mendalam, tidak hanya sekadar hafalan layaknya pengetahuan faktual.

Dalam aktivitas pembelajaran sebaiknya terfokus pada apa yang dinamakan proses-proses kognitif tingkat tinggi (Anderson et al., 2001). IPK untuk KD 3.1 hanya sampai pada IPK "Menentukan hasil operasi". Oleh karena tingkat kognitif mengaplikasikan (C3) melibatkan proses "penentuan" pilihan, siswa perlu diajarkan untuk memeriksa dan mengkritik hasil atau solusi akhirnya, dimana memeriksa dan mengkritik berada dalam tingkat kognitif mengevaluasi (C5). Sehingga, analisis terhadap aktivitas-aktivitas pembelajaran dengan kerangka Taksonomi untuk KD. 3.1 kelas IX dapat tergambarkan seperti pada tabel 2 (Adaptasi dari kerangka tabel Taksonomi Bloom oleh Krathwall \& Anderson):

Tabel 2.

Penempatan tujuan dan aktivitas pembelajaran dalam taksonomi pendidikan KD 3.1 kelas IX

\begin{tabular}{|c|c|c|c|c|c|c|}
\hline \multirow{2}{*}{$\begin{array}{l}\text { Dimensi } \\
\text { Kognitif }\end{array}$} & \multicolumn{6}{|c|}{ Dimensi Proses Koginitf } \\
\hline & C1 & $\mathrm{C2}$ & $\mathbf{C 3}$ & $\mathrm{C4}$ & $\mathbf{C 5}$ & C6 \\
\hline \multicolumn{7}{|l|}{$\begin{array}{l}\text { Pengetahuan } \\
\text { Faktual }\end{array}$} \\
\hline $\begin{array}{c}\text { Pengetahuan } \\
\text { Konseptual }\end{array}$ & & $\begin{array}{c}\text { Aktivitas 1 } \\
\text { (mengklasifi } \\
\text { kasikan jenis } \\
\text { masalah) }\end{array}$ & $\mathbf{U A N}$ & & $\begin{array}{c}\text { Aktivitas 6 } \\
\text { (mengkritik } \\
\text { ketetapan } \\
\text { solusinya) }\end{array}$ & \\
\hline $\begin{array}{c}\text { Pengetahun } \\
\text { Prosedural }\end{array}$ & & & $\begin{array}{c}\text { Aktivitas 2 } \\
\text { (mengiplemnetasikan } \\
\text { prosedur-prosedur yang } \\
\text { tepat) }\end{array}$ & & $\begin{array}{c}\text { Aktivitas 5 } \\
\text { (memeriksa } \\
\text { implementasi } \\
\text { prosedurny) }\end{array}$ & \\
\hline $\begin{array}{l}\text { Pengetahuan } \\
\text { Metakognitif }\end{array}$ & $\begin{array}{c}\text { Aktivitas } \mathbf{3} \\
\text { (mengingat kembali } \\
\text { strategi-strategi } \\
\text { metakognitif) }\end{array}$ & & $\begin{array}{c}\text { Aktivitas } 4 \\
\text { (mengimplementasikan } \\
\text { strategi-strategi } \\
\text { metakognitif) }\end{array}$ & & & \\
\hline
\end{tabular}




\section{JURNAL GANTANG. Oktober 2019; IV(2): 103 - 109 \\ p-ISSN. 2503-0671 \\ e-ISSN. 2548-5547}

Jika kita lihat pada tabel 2 yang dikembangkan oleh Krathwohl \& Anderson, terlihat bahwa tidak satupun kegiatan pembelajaran saling berkaitan secara langsung dengan tujuan. Hal ini dikarenakan, tingkat kognitif "mengaplikasikan" membutuhkan pengetahuan prosedural, artinya menggunakan suatu prosedur dalam keadaan tertentu. Karenanya, jika sifat-sifat operasi bilangan berpangkat, bilangan rasional, dan bentuk akar (pengetahuan koseptual) akan diterapkan maka harus melekat pada suatu prosedur (pengetahuan prosedural). Prosedur inilah yang akan memudahkan penerapannya misalkan menentukan hasil dari bilangan berpangkat, serta menentukan hasil operasi bilangan berpangkat dan bentuk akar.

Guru seharusnya menyusun aktivitasaktivitas yang mendukung tercapainya tujuan pembelajaran, aktivitas-aktivitas yang berkaitan dengan fakta, konsep dan prosedurnya harus ada untuk mencapai tujuan pembelajaran. Hal ini dikarenakan kompetensi dalam matematika menuntut siswa untuk mengembangkan pengetahuan konseptual, pengetahuan prosedural (Rittle-Johnson, 2017).

\section{Kesimpulan}

Mengembangan indikator pencapaian kompetensi artinya guru sebelum mengembangkan harus menganalisis $\mathrm{KI}$ dan $\mathrm{KD}$ terlebih dahulu, dengan cara melihat KKO. KKO yang ada pada KD hanyalah penanda bahwa kompetensi tersebut adalah Kompetensi minimal yang harus dicapai oleh siswa. Untuk itu, dalam mengembangkan indikator guru harus mencapai kompetensi yang lebih tinggi dari kompetensi minimalnya, dengan cara mensinkronkan antara tingkat kompetensi (pemahaman, proses, penerapan) dengan jenis indikator (kunci, pendukung, kompleks). Sehingga tujuan pembelajaran yang akan dicapai akan berada pada level yang lebih tinggi dan hirarki kompetensi tidak akan tumpang tindih.

\section{Ucapan Terimakasih}

Artikel ini merupakan publikasi hasil penelitian selama 2 Tahun dengan mengobservasi RPP yang dikembangkan peserta Program Profesi Guru (PPG) dalam Jabatan selama mereka melaksanakan perkuliahan dan praktek mengajar di Sekolah. Oleh karena itu penulis mengucapkan terimakasih kepada peserta PPG FKIP Unsri dan kepada Koordinator Prodi Pendidikan Matematika atas dukungannya demi kesuksesan penelitian ini.

\section{Referensi}

Anderson, L. W., Krathwohl Peter W Airasian, D. R., Cruikshank, K. A., Mayer, R. E., Pintrich, P. R., Raths, J., \& Wittrock, M. C. (2001). Taxonomy for_Assessing a Revision OF BlOOM'S TaxONOMy OF EducatiONal Objectives.

Delafani, R., Holilulloh, \& Nurmalisa, Y. (2014). Pengaruh kemampuan guru dalam mengembangkan indikator pencapaian kompetensi terhadap kesiapan guru dalam mengajar.

Depdiknas. (2010). Panduan Pengembangan Indikator.

Febrian, F., \& Fera, M. (2019). Kualitas perangkat dan keterampilan mengajar mahasiswa pendidikan matematika pada mata kuliah micro teaching menggunakan analisis model rasch. Jurnal Gantang, 4(1), 87-95.

https://doi.org/10.31629/jg.v4i1.1065

Nuraeni, Z. (2019). Implementasi penilaian berbasis portofolio untuk meningkatkan aktivitas dan hasil belajar mahasiswa semester 1 Pendidikan Matematika STKIP Muhammadiyah Kuningan. Jurnal Gantang. https://doi.org/10.31629/jg.v4i1.797

Rina Asih Handayani. (2015). Analisis kesesuaian antara materi dengan kompetensi inti dan kompetensi dasar kurikulum 2013 (Vol. 2013).

Rittle-Johnson, B. (2017). Developing mathematics knowledge. Child Development Perspectives. https://doi.org/10.1111/cdep.12229

S, P. I. (2017). Analisis kompetensi profesional "menguasai kompetensi inti atau kompetensi dasar dan pengembangan 
materi" guru PPKN di SMA Negeri 2

Purbalingga. In Universitas Sebelas Maret

Surakarta (Vol. 01).

Wagner, T. (2014). The Global Achievement Gap. Assessment.

Wardhani, S. (2010). Indikator pencapaian kompetensi matematika SMP / MTs. 